\title{
The Powerless Supernatural Creature as the Victim Figure in Roh dari Masa Lampau
}

\author{
Fitria Sis Nariswari ${ }^{1}$, M.Yoesoef ${ }^{2}$ \\ \{1 fitriasisn@gmail.com, 22yoesoev@yahoo.com\} \\ University of Indonesia
}

\begin{abstract}
The strongest emotion within human nature is fear[1], meanwhile, the strongest type of fear is the fear over the unknown[2]. Freud developed a concept called das Unheimliche that is related to stories which can trigger fear and terror. The horror stories permeated in Indonesia during the period of 19701990s were considered as the third-rate literature, even though it had a considerable amount of readers who were fans of these stories. During the period, several horror writers were coming into the spotlight. However, Abdullah Harahap, who were prominent among readers during 1970-1990s, turns to be a less-known writer when it comes to academic research. During the period, several horror writers were coming into the spotlight, such as Tara Zagita, Teguh S., Abdullah Harahap, or S.B. Chandra. Yet, only Abdullah Harahap who could set the record as the most productive horror writer compared to the others. This research examines Roh dari Masa Lampau (1981), a novel written by an Indonesian writer Abdullah Harahap. This research aims to reveal how the ideology of a literary work can impact the broader context of society. During this time, the discussion of Abdullah Harahap's work revolved around a mystery or erotic stories. The stories of Abdullah Harahap show that the supernatural creature pays its revenge using human as the medium. It shows that there is a definitive border between the worlds of supernatural and human. The border signifies that some particular matters cannot be crossed. Each creature has its own space; therefore, the presence of the other creatures will be considered as a threat.
\end{abstract}

Keywords: Abdullah Harahap, Roh dari Masa Lampau, powerless supernatural Creature, horror

\section{Introduction}

The talk on horror stories never ceased to be discussed, as ones will find any topics regarding horror stories, even in daily conversation. In academic circle, horror becomes one of the popular topics in the dialogue of genre in literature. Horror is also identical with supernatural elements used as a mean of storytelling[3]. Horror provokes strong responses. Self-appointed moral guardians are apt to condemn the genre sight unseen, while media coverage routinely scapegoats 'video nasties' in much publicized cases of violence and murder[4]. It is understandable that horror then gained its wide aficionados. The horror stories 
permeated in Indonesia during the period of 1970-1990s were considered as a third-rate literature, even though it had a considerable amount of readers who were fans of these stories. During the period, several horror writers came into the spotlight, such as Tara Zagita, Teguh S., Abdullah Harahap, or S.B. Chandra. Yet, only Abdullah Harahap who could set the record as the most productive horror writer compared to his colleagues. In the span of two decades, he had written more than 110 literary works (approximately 80 horror novels and 30 romance novels), short story anthologies, and several film scripts. He wrote the most literary works compared to other horror writers during the same period.

Abdullah Harahap's stories written in the 1970s to 1990s brought him to a broader scope of readers. His stories revolve around the horrifying narratives. His novels bear the same similarity, they highlight the idea of the social condition involving the local beliefs of shaman, heresy, myth, and legend that remain to endure within the mindset of the society. Additionally, he managed to incorporate supernatural and irrational events as an integral part in his stories. The idea of horror stories is also supported with the occurrence of elements such as sexuality, murder, violence, crime, and the presence of characters from the world of ghostly spirit. Another characteristic lays on the setting of location, in which the stories dominantly happen in places around East Java. Luxurious locations such as extravagant house with modern architecture design in a remote area, graveyard, or hill are also presented in most of his stories.

However, Abdullah Harahap, who were prominent among readers during 1970-1990s, turns to be a less-known writer when it comes to academic research. There are only two research found, conducted by Chotimah[5] and Darmawan[6], which discussed his works within the horror genre studies in the academic field. In addition to the aforementioned research, the discussion on Abdullah Harahap can only be found in blog writings[7] or a book's introduction[8]. However, his books are hard to find in bookstores but can be easily found in cigarette kiosks, preloved-book stalls, or train stations[8].

The above elaboration can be considered as one of the reasons why Harahap's works are important among the historiography of Indonesian literature. Even though Salam[9] stated that Harahap's works are less-important than the others since his works only considered as popular readings in the 1970s. He also mentioned that popular fiction is something that is less significant in its literariness and aesthetic aspect, therefore makes the works do not meet the standard to be examined academically. By putting Harahap in the said position, his works are not taken seriously by critics which resulted in the minimum amounts of research conducted on them. Nevertheless, cannon literary works and popular ones is difficult to compare due to their different criteria, construction, convention, and the history of its origination. Teeuw particularly pointed at a period around 1960s to 1969 when high-quality novels were hardly accessible, therefore novels, such as Harahap's - in precedence with the emergence of Motinggo Boesje - were a few fictions available during the time. In the context of this current era, popular literary works can be used as the chain that connects the interruption within the history of literature happened during the vacuum period of literature amid the crisis period in Indonesia[10].

However, it is interesting to look at the repetitive pattern in each of Abdullah Harahap's works. His stories hold the similarity of violence and abnormal sexuality theme that can be considered as a pattern that constructs the narratives. Abdullah Harahap's characteristic resulted from the consistency of violence and sexuality theme appeared in each of his stories, which simultaneously reckoned as the theme that closely related to Abdullah Harahap's journey as a writer.

This research used Roh dari Masa Lampau (1981) as the source of data with meticulous consideration that the novel is regarded to sufficiently represent the stories in other novels that 
exhibit the elements of violence, abnormal sexuality, and the troubled nuclear family relation. The novel be will analyzed from its plot to understand the narrative pattern. Plot and character analysis will be used to comprehend how violence and abnormal sexuality described in Roh dari Masa Lampau (1981).

This research aims to focus on the inability of supernatural creature to take revenge in Abdullah Harahap's stories. Additionally, this research questioned how the inability of supernatural creature to take revenge shows the boundaries between supernatural and humans world. Those become interesting because during this time the analysis of Abdullah Harahap is only about sexuality. Nevertheless, before entering the discussion, the researcher has compiled a short history of horror and Roh dari Masa Lampau (1981) synopsis in order to deliver a full understanding of the matter.

\section{Research Method}

The method used in this research will be explained in the following chart.

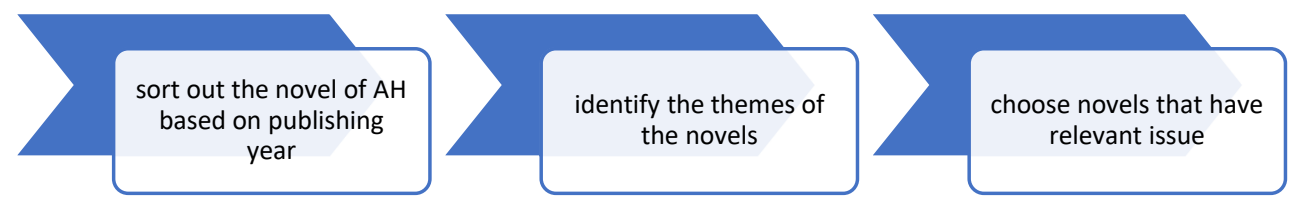

Chart 1. How to choose the data

\section{Results And Discussion}

\subsection{Synopsis of Roh dari Masa Lampau}

A village's harmonious life is disrupted following several bodies found dead in blue and blistered condition. The locals accused Hendra-a doctor recently moved from the city. Hendra is suspected to be responsible for the series of unusual death happened in the village based on the rumor that Hendra is a murder and a witch. However, the real murder is Maharani-a junior high teacher who also recently moved to the village from the same city as Hendra's. Maharani later is known to be possessed by the mountain forest's malevolent spirit.

The malevolent spirit holds a particular resentment towards Maharani and her husband for having sexual intercourse on the mountain - the home of the spirit. She possessed Maharani to take revenge on every man in the village. The story is ended with Maharani-who is being possessed by the spirit - cornered by the locals. The character of Abah holds an important role 
during the siege since Abah has the ability to talk to spirits. The malevolent spirit insists to stay in Maharani's body. Nevertheless, Abah's spell puts her in distress which resulted in Maharani's body being thrown into the fire.

\subsection{Plot of Roh dari Masa Lampau (1981)}

The description of Roh dari Masa Lampau (1981) unit of contents is listed below.

\begin{tabular}{|c|c|c|}
\hline No & $\begin{array}{c}\text { Unit of } \\
\text { Content }\end{array}$ & Description \\
\hline 1 & Exposition & $\begin{array}{l}\text { Maharani, who originally lived in the city, is being transferred to the village as a } \\
\text { teacher. } \\
\text { Maharani puts her concern and attention to Maya, the student accused by her } \\
\text { friends for being "the demon offspring". } \\
\text { Hendra-Maya's father-is suspected as a witch due to his mysteriousness. }\end{array}$ \\
\hline 2 & $\begin{array}{l}\text { Inciting } \\
\text { Incident }\end{array}$ & $\begin{array}{l}\text { The village is disrupted with the unnatural deaths: blistered and swollen bodies } \\
\text { while the faces are creased and wrinkled. } \\
\text { The locals start to accuse Hendra of being the one responsible for the deaths. }\end{array}$ \\
\hline 3 & Complication & $\begin{array}{l}\text { The number of unnatural death is increasing. } \\
\text { It is suspected that the victims had sex with a beautiful woman-who is } \\
\text { possessed by a malevolent spirit. } \\
\text { Maya who likes to visit the hills alone is accused to be the woman causing the } \\
\text { unnatural deaths. } \\
\text { Maya is rumored to be capable of meeting her mother's spirit. } \\
\text { Initiated by Jajang-Maharani's boyfriend, the locals gather in front of Hendra's } \\
\text { house to force him and Maya to take the responsibility of the unnatural deaths } \\
\text { happened in the village. } \\
\text { The locals beat Hendra, causing wounds all over his body. }\end{array}$ \\
\hline 4 & Climax & $\begin{array}{l}\text { While having sexual intercourse with Maharani, Jajang realizes that Maharani is } \\
\text { being possessed by a malevolent spirit and simultaneously learns that Maharani } \\
\text { is the real murder. }\end{array}$ \\
\hline 5 & Reversal & $\begin{array}{l}\text { Abah-the village's shaman-learns about Maharani and the malevolent spirit } \\
\text { possessing her. } \\
\text { Abah arrives, casts the spell, and spits on the spot where Maharani and Jajang } \\
\text { had sexual intercourse. }\end{array}$ \\
\hline 6 & Resolution & $\begin{array}{l}\text { The malevolent spirit and Maharani are in pain due to Abah's spell. } \\
\text { The malevolent spirit throws Maharani's body to the fire while she tries to leave } \\
\text { the woman's body. } \\
\text { Abah visits the grave of Hendra's wife to pick up Maya and asks the spirit of } \\
\text { Hendra's wife to voluntarily leave Maya. }\end{array}$ \\
\hline 7 & Denouement & $\begin{array}{l}\text { Maharani and her husband had sexual intercourse in the forest, turned the forest's } \\
\text { spirit in a rage, resulted in her taking revenge by possessing Maharani. } \\
\text { The husband is dead after having sexual intercourse with Maharani who has been } \\
\text { possessed by the spirit. } \\
\text { Hendra's wife died after being locked in a cupboard during a hide and seek game } \\
\text { with Maya, forcing Hendra and Maya to relocate to the village. However, } \\
\text { Hendra's wife followed Maya wherever she goes. }\end{array}$ \\
\hline
\end{tabular}

The table above indicates the act of revenge conducted by the malevolent spirit of the forest where Maharani and her husband had sexual intercourse. The plot also shows the tendency to avoid problems conducted by Hendra and Maharani. Hendra relocates from the city to the village to avoid rumors regarding his wife's death. Meanwhile, Maharani relocates from the city to the village to let go of her memory regarding her husband's unnatural death. It 
is interesting to find within the plot that the malevolent spirit is unable to take revenge. The latter topic will be discussed further in the next sub-chapter.

\subsection{Supernatural Creature: The Limitedness of the Victim Figure}

The appearance of supernatural creatures in Abdullah Harahap's stories is highly contextual. In most of his horror stories, the supernatural creatures bear the motive of revenge for its death. The supernatural creatures take form in ghostly spirits, incarnations, or malevolent spirit as found in Roh dari Masa Lampau. The supernatural creature takes form in a malevolent spirit who possessed Maharani's body. To comprehend the matter fully, the researcher explained in the table below.

Table 1 Supernatural Creature in Roh dari Masa Lampau

\begin{tabular}{|c|c|c|c|}
\hline No & $\begin{array}{c}\text { Supernatural } \\
\text { Creature }\end{array}$ & Origin & Agenda \\
\hline 1 & $\begin{array}{l}\text { - The spirit who } \\
\text { possessed } \\
\text { Maharani } \\
\text { The spirit of } \\
\text { Maya's mother }\end{array}$ & $\begin{array}{l}\text { The forest spirit whose home is used to be the } \\
\text { spot for Maharani and her husband to have } \\
\text { sexual intercourse. The husband also } \\
\text { accidentally peed on her face } \\
\text { Died because accidentally being locked in a } \\
\text { cupboard }\end{array}$ & $\begin{array}{l}\text { - } \quad \text { Take revenge on } \\
\text { Maharani and } \\
\text { her husband } \\
\text { - Wanting to meet } \\
\text { her daughter }\end{array}$ \\
\hline
\end{tabular}

The table above describes that revenge plays an important factor as the reason behind the presence of a supernatural creature in the novel. In Roh dari Masa Lampau, the malevolent spirit's appearance triggered by the things undone in the human world. However, if we look further, the malevolent spirit used a mediator to revenge. It can be concluded that the supernatural creature is powerless. It experienced several acts of violence, both physically and psychologically, even though it has transformed into a supernatural creature. The wish for revenge is reflected through the quotation below.

Jajang terbelalak. Cemas dan takut.

"Ia kencing!", ulang Maharani, menuding. "Ia kencingi kuburanku. Laki-laki busuk itu. Ia kencingi kuburanku. Aku .... aku sedang menghirup udara senja, ketika ia muncul, mengencingi kuburanku, bahkan air kencingnya sempat menciprat kemukaku. Hih, busuk dan pengik, menjijikkan ....", Maharani meludah, meludah dan meludah.

Abah membuka mulut tiba-tiba.

Keras suaranya :

"Bukan dia, bukan dia. Mungkin seseorang lain. Bukan dia. Bukan Maman. Bukan Ruhiyat. Bukan Joko. Bukan Jajang. Seseorang lain. Katakan padaku, wahai roh penasaran, siapa dia?"

"Laki-laki itu!", Maharani tampak meradang. Tegak kaku di tempatnya berdiri, menatap ke arah Abah yang masih bersimpuh. "Laki-laki kurang ajar! Laki-laki tak tahu adat! Dia .... Dia ..."

Apakah ia suami Maharani. Ia dan isterinya - hehehe .....", Maharani tertawa terkekeh-kekeh. "Maksudku, raga orang yang sekarang kutempati, benar-benar tak mau tahu di mana mereka ingin bercumbu!" (Roh dari Masa Lampau, h. 180)

Jajang eyes are wide-open. Anxious and scared. 
"He peed!", said Maharani, pointing her finger. "He peed on my grave. That rotten man. He peed on my grave. I... I was enjoying and breathing the afternoon breeze, when he came, and peed all over my grave, his urine even splattered on my face. Rotten and spiteful, disgusting..., "She spits and spits for more.

Suddenly, Abah opens his mouth.

He said loudly:

"It's not him. It's not. Could be someone else. It's not him. It's not Maman. Nor Ruhiyat. Nor Joko. Nor Jajang. It's someone else. Tell me, spirit, who is he?"

"That man!" Maharani enrages. She stands upright and stiff, looking at the direction where Abah humbly sits. "The insolent man! The immoral! He... He..."

"Is it Maharani's husband? Him and his wife - hehehe...." Maharani frantically giggling. "I mean, the body I possessed now, had no idea where they should devour each other!” (Roh dari Masa Lampau, p. 180)

The quotation above shows the conversation exchanged between Abah and the sprit possessing Maharani's body during the attempt of forcing her to leave Maharani's. The revenge conducted by the spirit possessing Maharani's body has two possibilities. Firstly, it shows that she has a particular limitedness to take the revenge with its own hands, therefore it needs to borrow Maharani's body as a vessel to revenge. Secondly, its biggest grudge is addressed to Maharani instead of her husband, therefore it possessed Maharani in order to put the woman in a great pain. When the spirit succeeded to kill Maharani's husband, she continues to take revenge to every man who are close to Maharani. The spirit cannot be satisfied by killing the husband. The spirit — gendered as a woman - holds the greatest grudge to Maharani can also be seen as an act of a woman who considered the other women as competitors.

Based on the explanation in the previous paragraph, it can be concluded that the supernatural creature appears as a powerless figure. The spirit who possessed Maharani had no power to fight Maharani and her husband when they were having sexual intercourse within its territory. During that time, the spirit had no capability to take revenge on Maharani and her husband. Nevertheless, the spirit uses Maharani as a media to revenge. The powerless creature is emphasized as having no ability to revenge in its supernatural form. It seeks for a media or someone else to conduct the revenge.

Avery F. Gordon stated that the presence of ghostly spirits in everyday life signifies something that is missing in the society[11]. The revenge that is conducted by using someone else's hands indicates that there are several borders between the worlds of human and supernatural creatures. The limitation appears since each of them belongs to a different world. Therefore, the supernatural creature needs a mediator to connect and revenge. Additionally, it also shows that one is unconfident due to the loss or incompleteness within oneself, resulting in channeling the distress towards someone else.

Such an explanation can be found in Roh dari Masa Lampau, the malevolent spirit possessed Maharani in order to revenge using someone else's hand. The spirit had been lived a peaceful period in thousands years in the forest until Maharani and her husband made love on its grave, the husband even peed and splattered it on its face. The spirit experienced a threat within its territory[12], therefore it deserves to feel disturbed. However, as a figure of spirit, it 
is powerless when it comes to confront human using its own hands. The spirit considered to revenge using Maharani's body, as described in the quotation below.

"Aku sudah dikubur ribuan tahun di hutan itu!" Maharani berteriak lengking dan parau. "Semua orang tahu. Semua orang sudah diperingatkan, agar jangan berani-beraniin melanggar wilayah kekuasaanku. Tetapi laki-laki itu, dan orang yang raganya kini kutempati ... benar-benar tak tahu diri. Mereka bersenggama disamping kuburanku yang ditumbuhi semak belukar ... Huh, sialan. Mengapa taka da orang yang membersihkan kuburanku .... Hihihii", ia meringkik lagi. "Aku terangsang juga oleh mereka berdua. Selagi aku terbuai nafsuku sendiri, eh ... laki-laki berbau busuk itu tiba-tiba telah bangkit dan kencing seenaknya di depanku. Di kuburanku. Bahkan dimukaku. Kurang ajar! Tak tahu diadat! Tak menghormati leluhur! Tak ...." (Roh dari Masa Lampau, h.181)

"I have been buried in this forest for thousands years!" Maharani screaming frantically in raucous voice.

"Everyone knows. Everyone has been warned, don't ever crossed the rules in my territory. But that man, and the woman I'm in now...have no respect to themselves. They had sex next to my grave with shrubs around it ... Damn it! Why did nobody tend my grave .... Hihihihi", she neighing. "I was aroused by them. While I was consumed by my own desire, that rotten man suddenly stand up and peed in front of me. Even on my face. What an immoral! Uncultured swine! Has no respect to the ancestors! Don't ...." (Roh dari Masa Lampau, p.181)

The quotation shows the conversation between the spirit who possessed Maharani during an interrogation with Abah. The spirit murdered Maharani's husband using her hands. It does not stop there, the spirit also killed several innocent men to satisfy its sexual desire which was aroused when looking at Maharani and her husband making love. All of these conducts are done through the hands of Maharani, including throwing the woman's body into the fire. Moreover, the reason behind the revenge based on the consideration that Maharani and her husband do not respect the ancestors. In this sense, the background of culture within the story can be seen as a culture that posits the ancestors as something worth to be respected.

Furthermore, it also shows that the spirit who possessed Maharani is defending its territory from the outsiders. She considers that Maharani and her husband bring a particular threat and their visit is not welcomed by her. The attempt to defend the space of power is also considered as a threat from the perspective of human. The spirit, even though metaphorically, has its power over Maharani's body, while in fact, the spirit hides behind Maharani's in order to gain power over the supernatural world and the human world.

In the context, this research shows that supernatural creature basically has limitations that are covered by mastery over human. This also shows that Abdullah Harahap's stories are complex stories. It not only presents sexuality, but also social problems. The struggle for space that occurs between humans and supernatural creature shows that there are things that have been missed: no creature wants its existence to be shifted, especially by the system. 


\section{Conclusion}

Based on the discussion above, the supernatural creature pays its revenge using human as the medium. It shows that there is a definitive border between the worlds of supernatural and human. The border signifies that some particular matters cannot be crossed. Each creature has its own space; therefore, the presence of the other creatures will be considered as a threat.

\section{References}

[1] H.P. Lovecraft, Supernatural Horror in Literature. New York: Dover, 1933.

[2] Brigid Cherry, Horror. London: Routledge, 2009.

[3] T. A. Society, T. Journal, and A. Criticism, "Horror and Humor Author ( s ): Noël Carroll Source: The Journal of Aesthetics and Art Criticism, Vol . 57, No .2, Aesthetics and Popular Culture ( Spring , 1999 ), pp . 145-160 Published by: Wiley on behalf of The American Society for Aesthetics Sta," vol. 57, no. 2, pp. 145-160, 2017.

[4] "WHY HORROR $\square$ THE PECULIAR PLEASURES OF A POPULAR GENRE.pdf.".

[5] Chusnul Chotimah, "Cerita Seram Abdullah Harahap," Fak. Ilmu Pengetah. Budaya, 2014.

[6] A. Darmawan, "Unsur-Unsur Gotik dalam Novel Penunggu Jenazah Karya Abdullah Harahap," Metasastra, vol. 8, no. 2, 2015.

[7] I. Seminar, O. Recent, F. S. Nariswari, and M. Yoesoef, "Violence and Abnormal Sexual Behavior in Titisan Iblis by Abdullah Harahap," vol. 280, no. Basa, pp. 91-97, 2018.

[8] U. P. Eka Kurniawan, Intan Paramadhita, Kumpulan Budak Setan. Jakarta: Gramedia Pustaka Utama, 2010.

[9] A. Salam, "Posisi Fiksi Populer di Indonesia," Humaniora, vol. XIV, no. 2, 2002.

[10] “Author ( s ): A . TEEUW MODERN INDONESIAN LITERATURE,” no. 1971, pp. 256-263, 2017.

[11] I. Pinedo, "Elements of the Postmodern Contemporary Horror Film Isabel Pinedo Recreational Terror :," Film, vol. 48, no. 1, pp. 17-31, 2012.

[12] P. J. Kain and P. J. Kain, "AND THE HORROR OF EXISTENCE the center," vol. 23, no. 1, pp. 41-58, 2018. 